\title{
The Use of Blended Learning Model Integrated with Learning Management System in Volleyball Learning Subject in Faculty of Sports Science State University of Malang
}

\author{
M.E. Winarno, Taufik, Nurrul Riyad Fadhli, Dona Sandy Yudasmara \\ Faculty of Sports Science \\ Universitas Negeri Malang \\ Malang, Indonesia \\ m.e.winarno.fik@um.ac.id
}

\begin{abstract}
The purpose of this research was to develop volleyball learning product using blended learning model integrated with E-learning of State University of Malang (UM). The research method used was the research and development method (R\&D), with the following steps (a) needs analysis, (b) initial product development and expert judgment in the form of (1) video of volleyball learning, (2) textbook (E-book) of volleyball, and (3) blended learning model of volleyball integrated with learning in UM, and (c) group test and experiment test to test the effectiveness. The result of the research obtained a valid product from volleyball experts, teaching media experts, and blended learning experts. This product was effectively used by a small group which was $80.95 \%$ and a large group which was $84.79 \%$. The blended learning model I was better and more effective than the blended learning model II, the product created by the blended learning model was integrated with learning management system of State University of Malang which consists of a video of volleyball learning, E-book of volleyball learning and blended learning model I and II.
\end{abstract}

Keywords - Learning, volleyball game, blended learning

\section{INTRODUCTION}

Learning is an activity that is generally known as a human effort to improve individual's ability. In learning activities, learning process, which is the essence of human life, occurs. Learning is a process to obtain changes that are made consciously, active, dynamic, systematic, sustainable, integrative, and that have clear goals. Learning activities are the efforts done by humans to change the behavior in life towards a better life. Humans use various ways in learning. One of them is involving the others as learning resources. The interaction between human and the others is referred to as learning activities. Based on Santrock [1], learning can be defined as a permanent influence on the behavior, knowledge, and thinking skills acquired through experience. Learning is a process involving learners in activities. There are several types of learning activities conducted by humans. There are some major domains in the perspective of human learning activities.

Bloom [2], mentioned that the learning domains which can be improved in learning activity are an affective, cognitive, psychomotor and physic domain. Another opinion expressed by Annarino [3], is that the domain of learning that must be improved is the affective, cognitive, psychomotor and physical domains. Affective domain is related to personal, social and emotional development. Cognitive domains are affiliated with intellectual knowledge, abilities, and skills. Psycho mechanical domains are about perceptual-motor ability and basic movement skills. Physical domains are regarding the physical abilities.

One of the learning aspects done by humans is motion learning. Motion learning is a learning activity through the activities of human body movement. Motion learning is a set of processes connected with practice or experience that lead to create a relatively permanent change in one's ability to display skilled-movements [4]. This motion learning activity has the goal of achieving a change in human's motion behavior. One way to learn this motion is through exercise. The purpose of the exercise is to make learners have good competence through fun activities that can increase the confidence in conducting activities during the learning period (semester) which will motivate the learners to always keep learning and improve learning opportunities at all times [5]. The learning movement is expected can facilitate learners to improve psychomotor competence to develop better. The design of learning activities can be done in various ways so that the learning process becomes more effective.

The learning process at the State University of Malang uses a semester credit system (SCS) as well as the learning at the other universities. Semester credit system (SCS) is used as a measure of student learning load, as well as the load of lecturers in the learning process. The process of one creditlearning activities are equivalent to at least three learning 
activities per week and per semester consisting of scheduled lectures which are 1 hour of lecturing or 2 hours of practice or 4 hours of fieldwork in a week, each of which is accompanied by about 1-2 hours of structured tasks and about 1-2 hours of independent activities. (Educational Guideline of State University of Malang, 2015). The course of Volleyball contains the curriculum of the Department of Physical and Health Education, Department of Sports Science and Sports Coaching Education at the Faculty of Sports Science, consists of 2 SCS and 2 JS, with $2 \times 50$ minutes face-to-face, $2 \times 60$ minutes structured and $2 \times 60$ minutes stand-alone task. The purpose of the volleyball lecture is the students have the knowledge and skills in performing basic techniques of volleyball games, possess knowledge and skill in performing techniques and mastering teaching methodology and organization of volleyball matches. Materials taught in the volleyball course are basic passing and bottom passing techniques, basic service techniques and bottom services, basic techniques of smash, basic block techniques, playing volleyball exercises and mastering learning methods in volleyball. (Catalogue of Faculty of Sports Science, 2016).

The volleyball game is a ball-shaped sport in the air back and forth over the net with the intention of dropping the ball inside the opponent's field to seek victory. The volleyball game is a team game on a length of $18 \mathrm{~m}$ and $9 \mathrm{~m}$ width, bordered by a $5 \mathrm{~cm}$ wide line. The middle of the field is a $9 \mathrm{~m}$ long line that splits the field into two equal areas. Straight on it is net, with height of $2.43 \mathrm{~m}$ and $2.24 \mathrm{~m}$ for a princess. There are two teams facing each other and each team has 6 players, 3 players as attackers and 3 others as defending [6]. The volleyball game is a game done together because it is a team sport. The volleyball game should be in a field divided by two equal surfaces of areas. According to Sugiono, the volleyball game is a team sport that is played by six people per team [7]. This game will work well if every player has at least mastered the basic techniques of playing volleyball. PBVSI (2005) stated that volleyball is a sport played by two teams in a field separated by a net. Thus, it can be deduced that volleyball is a game played by six people per team and performed on a rectangular field, in the middle of a restricted net of which function is to separate players between teams.

The approach and implementation of learning are adapted to the description and objectives of volleyball learning lectures. The learning methods used were lectures, exercises, parts, whole and drill that were all still implemented in direct modeling in the lecture so that this approach resulted in less focused learners during lectures due to fatigue factor and boredom. Based on the researchers' experience in having volleyball learning process, it was found that the improvement of the performance result in pre-test and post-test had no significant difference level. It was caused by the lecturing process that was still dominated by face-to-face class without having systematic structured and autonomous assignment.
TABLE I.

Percentage Of THE Result of THE Students' Post-TEST IN VOLLEYBALL SUBJECT

\begin{tabular}{|l|l|l|}
\hline Range of score & Code & Percentage \\
\hline $85-100$ & A & $11.36 \%$ \\
\hline $80-84$ & A- & $11.36 \%$ \\
\hline $75-79$ & B + & $31.82 \%$ \\
\hline $70-74$ & B & $13.64 \%$ \\
\hline $65-69$ & B- & $17.05 \%$ \\
\hline $60-64$ & C + & $9.09 \%$ \\
\hline $55-59$ & C & $1.14 \%$ \\
\hline $50-54$ & D & $2.27 \%$ \\
\hline $0-49$ & E & $2.27 \%$ \\
\hline \multicolumn{2}{|c|}{ a. Score is taken from 88 students (2 classes) in Volleyball subject }
\end{tabular}

The efforts to maximize the structured task by recording material and compiling with the other sources are arranged into daily tasks and requirements for students to be able to follow the next lecture which has been done, but the researchers got difficulty to control the activities of students in the implementation of structured tasks and independent tasks, so that the results of students learning are still below the standard of graduation standards. Judging from the problems mentioned above, an integrated learning innovation between face-to-face meetings, structured tasks and independent tasks to maximize learning outcomes of the volleyball lectures are necessary.

Blended learning is the present and the future learning that should be mastered by the lectures, in which they seeks to unite the offline (non-online) and online learning systems. The learning method can be used as a solution to the learning problems found so that to attain better learning outcomes. The innovation of learning methods that utilize the development of technology and communication is also needed to increase the variety of learning. The blended learning method is an alternative method of learning which is better than the traditional method, the use of blended learning strategy is significantly better than the strategy of face-to-face learning in providing learning statistical concepts [8]. [9]It can be concluded that in this volleyball technique and practice, lectures can use blended learning method to improve the competence skill of students of the Faculty of Sports Science, State University of Malang, following the course of Volleyball technique and practice.

The blended learning method requires the preparation of more varied teaching materials because the teaching material is an essential learning resource for the learners, the majorities (76.2\%) of the respondents included the dictates/books/journals in the learning design while the teaching materials in audio and audiovisual formats did not become a significant part in learning. Nevertheless, some teachers have used the computer (40.6\% and internet (31.8\%) [9]. The importance of learning material is also necessary for learning volleyball, teaching materials that need to be developed in volleyball lectures are videos of volleyball learning and learning book of volleyball learning so that students do not only directly learn in face-toface lecture time.

Planning and implementation of blended learning require teaching materials and systems that can be used in online and offline interactions between the faculty and students, two-way interaction that allows students to interact anytime and anywhere. Such a system has been developed by the State 
University of Malang as an effort to improve the learning and teaching process. The E-Learning System of State University of Malang has a feature for two-way interactions between lecturers and students, so it is appropriate if the learning of volleyball uses blended learning method integrated with Learning Management System (LMS) of State University of Malang.

The purpose of this research is to: (1) develop volleyball product using valid blended learning model integrated with learning management system of UM (2) develop effective blended learning product integrated with learning management system of UM (3) develop blended learning product that is practically used and integrated with learning management system of UM.

\section{METHOD}

The design of this research used research and development method (R\&D). The development model used by the researchers was a procedural development model. This research and development procedure applies the following eight steps: (1) analysis of blended learning needs, (2) initial product development; (3) expert evaluation, (4) product revision I, (5) small group trial, (6) product revision II, (7) revision of product I, large group trials, and (8) test of the effectiveness of product development.

The instrument of data collector was observation conducted by the researchers that was nil participation observation by observing the learning condition of volleyball and participant observation observing the small group trial process and large group trial and product effectiveness test. The field note in this research was used to obtain information of the implementation of the initial conditions of volleyball learning process, expert test, field trials, and product effectiveness test of volleyball blended learning model integrated with e-learning of the State University of Malang. The form of the questionnaire was also used in this study. There are several forms. The first form is a multiple-choices questionnaire with Likert Scale.

Based on the type of the obtained data, the data in this study were processed using quantitative and qualitative approach. The description is as follows. (1) The quantitative approach was used to collect the data of (a) the assessment of volleyball experts, qualitative approaches were used to collect the data from expert evaluation, consisting of 2 volleyball and 1 instructional media experts. The obtained data were assessed regarding the product design to be developed. (b) The data of student assessment were obtained through small and large group trials. (c) Initial and final test results of product effectiveness tests. (2) A qualitative approach used the steps including data reduction, data categorization, synthesizing and compiling work hypothesis.

\section{RESULTS}

The results of this study consist of preliminary research results, the results of research trials of the product, and the results of the test phase of product effectiveness are presented in Table 2.
TABLE II. SUMMARY OF RESEARCH RESULT

\begin{tabular}{|c|c|c|}
\hline No & Component & Findings \\
\hline 1 & $\begin{array}{l}\text { Introduction Phase } \\
\text { a. Needs analysis } \\
\text { Observation of } \\
\text { implementation and } \\
\text { learning outcomes of } \\
\text { volleyball evaluation } \\
\text { b. Theoretical review } \\
\text { c. Development of product }\end{array}$ & 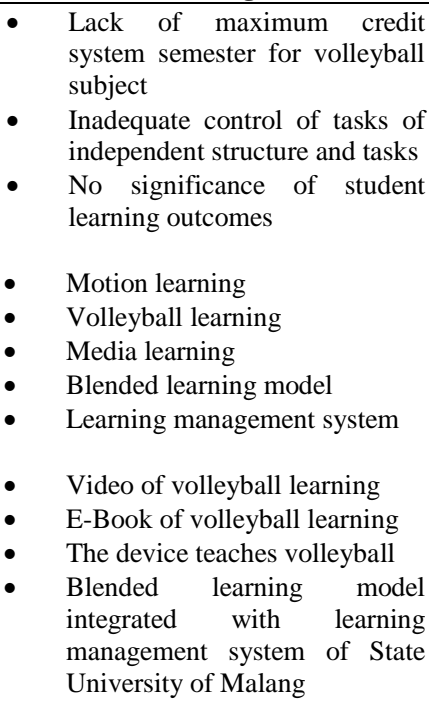 \\
\hline 2 & $\begin{array}{l}\text { Product Test Phase } \\
\text { a. Expert of volleyball } \\
\text { b. Expert of Learning media } \\
\text { c. Expert of blended learning } \\
\text { d. Field trials } \\
\text { Small group } \\
\text { Large group }\end{array}$ & $\begin{array}{ll}\text { - } & \text { Validation results } 85 \% \\
\text { - } & \text { Validation results } 87 \% \\
\text { - } & \text { Validation results } 95 \% \\
\text { - } & 80.947 \% \\
\text { - } & 84.791\end{array}$ \\
\hline 3 & Test of product effectiveness & $\begin{array}{l}\text { Blended learning model is better and } \\
\text { more effective than the conventional } \\
\text { learning model }\end{array}$ \\
\hline 4 & Product & $\begin{array}{l}\text { Learning blended learning model } \\
\text { integrated with leaning management } \\
\text { system of State University of Malang } \\
\text { - Video of volleyball learning } \\
\text { - E-book of volleyball learning } \\
\text { - Blended learning model that is } \\
100 \% \text { face to face, } 100 \% \\
\text { structured task, and } 100 \% \\
\text { independent task }\end{array}$ \\
\hline
\end{tabular}

\section{DISCUSSION}

The researchers will discuss the results of research from the introduction stage, product preparation, product testing and product effectiveness test. The goal to provide further interpretation of the results of data analysis has been proposed associated with relevant theories and previous research.

\section{A. Stage Introduction}

Research and development is a research that develops new products or existing products developed again in accordance with the conditions of progress now, product development into problem-solving solutions that arise in the phenomenon of society. The development research does not always develop new products, it can refine existing products that can be accounted for. Research and development is always preceded by the needs, problems that require solving by using a particular product. Research and development is a new research alternative to narrow the gap between quantitative and 
qualitative research; development research is perfect for education and sports. The preliminary stage in the development research consists of three stages: needs analysis, theoretical studies, and early product development.

\section{1) Needs Analysis}

The usual requirement analysis also known as the preliminary study is the first stage by the researchers to capture the phenomenon that occurs in the field which later checked with related theories, whether there is a gap between expectations with reality. According to Winarno [10], "the problem is a gap between expectations with reality, the gap between theory and practice that requires answers, explanations or solutions."

According to Arikunto [11], "Preliminary study is an activity undertaken by prospective researchers to conduct temporary data collection in development research to photograph problems that appear in the field to be the focus of the problem that will be raised as a topic in a development study. Borg and Gall conclude that needs analysis is the initial collection of information on differences in existing conditions in the field and desired conditions, for the need of solving the existing problem [12]." The next stage after the initial data were collected from the needs analysis, the researchers focused on the problem that would raise a topic of research, and then make the scope of the problem to limit the problem of research. The next step, the researchers prepared research proposals and make a planned research as a whole.

The problems in the field could be photographed by the researchers using diverse instruments such as interviews, observations, tests, and questionnaires. The selection of the instrument must be considered by the researchers for the phenomenon that appeared and could be photographed well and accurately. The focus of research in this study was learning, in this case, the researchers chose volleyball exercise because based on the experience of the researchers in volleyball courses in the Faculty of Sports Science, State University of Malang, there are many phenomena of the polarity between theory and practice. Following the phenomenon that researchers faced, the need analysis should be done using instrument of interviews with the other volleyball course tutors. The results of requirement analysis of this research are (1) less maximal credit system semester for college volleyball, (2) weak control of the independent structure tasks and tasks, and (3) no significance between process and student learning outcomes.

The semester credit system is the student's learning load, as well as the lecturers' load in the learning process. The system enables the gradual learner management is encoded in the faceto-face process, the assignment of structures and self-financing. The semester credit system can have a significant effect on the increase in the student's learning achievement [13]. FFCS (Fully Flexible Credit Semester) 'learning experience. It is concluded that there is a strong effect of FFCS on academic performance as well. The system performance that is not done for the most part of a lesson learned is more difficult to achieve.

Giving an assignment to the students is an effort to facilitate the learning process. The assignment can be carried out in a structured manner, that is, through the design given by the lecturer and done independently, where the students are expected to independently increase their knowledge of the field of science by multiplying the reader of the learning support. The criteria of each member must have different results of different learning [14]. These physical properties are effective to increase the activity of classmates in every charity and tasks but they can also improve the academic behavior of the students [15]. The assignment to the mantras is expected to meet the tasks of the lesson learned.

\section{2) Theoretical Review}

The stages of theory review are the stage before making the initial product design, and theory studies based on the results of needs analysis obtained from interviews and observations conducted by the researchers. Borg and Gall concluded, "Theoretical study is the collection of supporting research information related to development planning" [12]. The study of theory serves as a tool to review existing material based on scientific and empirical theory. The study of theory in this research is the theory of volleyball, the theory of motion study and biomechanics, the theory of the development of motion and the theory of exercise.

The selection of theories was based on the problem topics from the results of the needs analysis and the results of empirical thinking. The first theory is the theory of motion learning which is in accordance with the characteristics of the material presented.

- Volleyball Learning

- Media learning

- Blended learning model

Learning management system of the theory comes from a common idea to a particular idea or a deductive path. Winarno stated "deductive reason starts from the things that are general and go to the things that are special" [10]. Things that are wide enough or large enough coverage of the discussion were reviewed first so that later would be on the more specific. The researchers used deductive reasoning in the preparation of theoretical studies by revealing studies of the sport to favorable reviews of the research being compiled. This arrangement is relevant to the procedures and theories on which it is based and can show the logical reasoning flow of the researchers.

\section{3) Preparation of the Trial Product}

Preparation of the initial product is the draft of initial product stage; the initial product in this research is "the development of volleyball learning using blended learning model integrated with learning management system of the State University of Malang.

\section{B. Product Development Stage}

Phase 2 of the product trial was the stage to complete the initial product development based on the results of expert trials and field trials

\section{1) Expert Trial}

The expert trial in the process of research development is a research effort to obtain the expert assessment and input on 
initial product development, in this case, the experts of volleyball consisted of expert academics and expert practitioners. The results of the expert assessment of volleyball based on quantitative and qualitative data were the assessment results became the benchmark of the researchers, whether the initial product proceeded to the next stage or was continued with revision or unfit to continue.

\section{2) Main Field Testing}

Field trials are the stages for product development test of research subjects; the purpose is to know the application of the developed product and obtain the research subject's response to the developed product.

\section{3) Test Product Effectiveness}

Product effectiveness test using quasi-experimental design, compared the two groups between the experimental groups using blended learning model I and blended learning model II. Based on the analysis result, the blended learning I model was more effective to improve the student's skills to master the ability of passing and volleyball technique compared to the blended learning model II.

Offline learning is essential to keep doing because the delivery of information directly from the learner is very essential to address a positive image to the learner. As an adjunct to the offline learning activity, the use of learning media is effective to do. E-learning is one of the most effective mediums in the community today to support offline learning. Learning uses has a significant impact on the student achievement [16]. The variation of the learning medium will, of course, arise the attraction of the school in the learning activity. As an endorsement of these offline learning activities will result in online learning.

Online learning is a lesson that represents the activity of a global based on us [17]. This learning design is an attempt to respond to the global challenges that have occurred in the community. The effectiveness of the technology is not independent of the devices connected to the online network. The trend of home-based ventures has a positive correlation to mobile devices [18]. The use of mobile devices has more effects than that of laptops [19]. Another analysis of $\mathrm{Xu}$ and Jaggars [20] mentioned that online learning could enhance and support the activities of the other lessons and are used in all schools. As far as online learning is so useful, it can be utilized is to improve the quality of academics.

Blended learning-based learning is a learning that combines both offline and online approaches. This learning allows a learner to undertake learning activities anywhere, anytime and with anyone. Blended learning-based learning is not aimed at reducing the number of student attendance on face-to-face, but in addition to student learning activities to more anticipate the absence of lecturers and the others [21]. The implementation of blended learning model can improve student academic performance [22]. Some characteristics of the student's background (mental maturity, attitudes, computer mastery, competence, gender, and workload) can be used as a basis in implementing blended learning model [23]. It is expected that with the learning model, student learning activities can be facilitated well.

\section{CONCLUSION}

Learning volleyball using blended learning model integrated with learning management system is very suitable to apply. Blended learning can facilitate student learning activities to always be implemented anywhere and anytime. Students can take advantage of all learning resources to increase their skill level in a volleyball game beyond the lecture schedule with materials which are accessible via e-learning. It is expected to meet the elements in the established semester credit program and become the control of the task that must be accomplished by the students.

\section{REFERENCES}

[1] J. W. Santrock, "No TitA topical approach to lifespan development (M. Ryan, Ed," New York, NY McGraw-Hill Companies, Inc.(Original Work Publ. 2002), pgs, vol. 26, no. 30, p. 478, 2008.

[2] B. S. Bloom and L. A. Sosniak, Developing talent in young people. Ballantine Books, 1985

[3] A. A. Annarino, C. C. Cowell, and H. W. Hazelton, Curriculum theory and design in physical education. Mosby, 1980.

[4] R. A. Schmidt, "Motor learning principles for physical therapy," in Contemporary management of motor control problems: Proceedings of the II STEP conference, 1991, pp. 49-64.

[5] D. Siedentop, P. A. Hastie, and H. Van der Mars, Complete guide to sport education. Human Kinetics, 2011.

[6] B. . Viera and B. J. Fergusson, Bolavoli Tingkat Pemula. Jakarta: Raja Grafindo Persada, 2000.

[7] I. Sugiono, Sejarah, teknik, strategi dan metode permainan bola voli / Imam. Malang: Bagian Proyek OPF IKIP Malang, 1997.

[8] S. Sudarman, "Pengaruh strategi pembelajaran blended learning terhadap perolehan belajar konsep dan prosedur pada mahasiswa yang memiliki self-regulated learning berbeda," J. Pendidik. dan Pembelajaran, vol. 21, no. 1, pp. 107-117, 2014

[9] W. D. Dwiyogo, “Analisis Kebutuhan Pengembangan Model Rancangan Pembelajaran Berbasis Blended Learning (PBBL) Untuk Meningkatkan Hasil Belajar Pemecahan Masalah," J. Pendidik. dan Pembelajaran, vol. 21, no. 1, pp. 71-78, 2014.

[10] M. E. Winarno, Metodologi penelitian dalam pendidikan jasmani. Malang: Universitas Negeri Malang, 2007.

[11] S. Arikunto, Prosedur Penelitian: Suatu Pendekatan Praktik. Jakarta: Rineka Cipta, 2006.

[12] W. R. Borg and M. D. Gall, Educational research: An introduction. New York \& London: Longman Publishing, 1983.

[13] S. Zafar, B. Manjurekar, N. P. Kumar, and Z. A. Khan, "Effects of FFCS (Fully Flexible Credit System) on Learning Experience and Academic Performance," Procedia-Social Behav. Sci., vol. 143, pp. 4-7, 2014.

[14] J. Dunlosky, K. A. Rawson, E. J. Marsh, M. J. Nathan, and D. T. Willingham, "Improving students' learning with effective learning techniques: Promising directions from cognitive and educational psychology," Psychol. Sci. Public Interes., vol. 14, no. 1, pp. 4-58, 2013.

[15] M. T. Mahar, S. K. Murphy, D. A. Rowe, J. Golden, A. T. Shields, and T. D. Raedeke, "Effects of a classroom-based program on physical activity and on-task behavior," Med. Sci. Sports Exerc., vol. 38, no. 12, pp. 2086-2094, 2006.

[16] N. A. Oye, N. Iahad, M. J. Madar, and N. Rahim, "The impact of elearning on students' performance in tertiary institutions," Int. J. Comput. Networks Wirel. Commun., vol. 2, no. 2, pp. 121-130, 2012.

[17] M. Poe and M. Stassen, "Teaching and Learning Online: Communication, Community, and Assessment," A Handbook for UMass Faculty. Office of Academic Planning and Assessment, University of Massachusetts, Amherst, 2002.

[18] H. H. Chung, S. C. Chen, and M. H. Kuo, "A study of EFL college students' acceptance of mobile learning," Procedia-Social Behav. Sci., vol. 176, pp. 333-339, 2015. 
[19] Y. T. Sung, K. E. Chang, and T. C. Liu, "The effects of integrating mobile devices with teaching and learning on students' learning performance: A meta-analysis and research synthesis. Computers \& Education, 94, 252-275.," A meta-analysis Res. Synth. Comput. Educ., vol. 94, pp. 252-275, 2016.

[20] D. Xu and S. S. Jaggars, "The impact of online learning on students' course outcomes: Evidence from a large community and technical college system," Econ. Educ. Rev., vol. 37, pp. 46-57, 2013.

[21] K. Kabassi, I. Dragonas, A. Ntouzevits, G. Pomonis, T., Papastathopoulos, and Y. Vozaitis, "Evaluating a learning management system for blended learning in Greek higher education," Springerplus, vol. 5 , no. 1 , p. 101, 2016

[22] J. C. Almenara, M. D. C. L. Cejudo, and J. A. M. Lozano, "Contributions to e-Learning from a Best Practices Study at Andalusian Universities," Int. J. Educ. Technol. High. Educ., vol. 10, no. 1, pp. 226239, 2013.

[23] M. J. Kintu, C. Zhu, and E. Kagambe, "Blended learning effectiveness: the relationship between student characteristics, design features and outcomes," Int. J. Educ. Technol. High. Educ., vol. 14, no. 1, p. 7, 2017. 